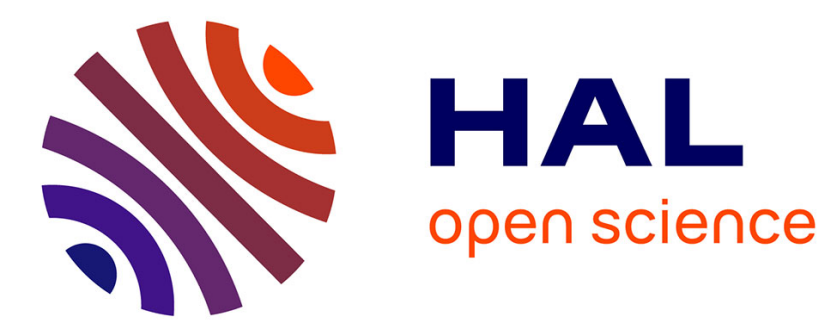

\title{
How long does it take to earn a higher education degree in Spain?
}

\author{
Gérard Lassibille, María Lucía Navarro Gómez
}

\section{To cite this version:}

Gérard Lassibille, María Lucía Navarro Gómez. How long does it take to earn a higher education degree in Spain?. Procedia - Social and Behavioral Sciences, 2010, 2 (2), pp.3519-3523. 10.1016/j.sbspro.2010.03.544 . halshs-00525614

\section{HAL Id: halshs-00525614 https://shs.hal.science/halshs-00525614}

Submitted on 21 Jul 2021

HAL is a multi-disciplinary open access archive for the deposit and dissemination of scientific research documents, whether they are published or not. The documents may come from teaching and research institutions in France or abroad, or from public or private research centers.
L'archive ouverte pluridisciplinaire HAL, est destinée au dépôt et à la diffusion de documents scientifiques de niveau recherche, publiés ou non, émanant des établissements d'enseignement et de recherche français ou étrangers, des laboratoires publics ou privés.

\section{(ㅇ)(1) $\$$}

Distributed under a Creative Commons Attribution - NonCommercial - NoDerivatives $\mid 4.0$ 
WCES-2010

\title{
How long does it take to earn a higher education degree in Spain?
}

\author{
Gérard Lassibille $^{\mathrm{a}}$, $\mathrm{M}^{\mathrm{a}}$ Lucía Navarro Gómez ${ }^{\mathrm{b}}$ \\ anstitut de Recherche sur l'Economie de l'Education, CNRS, Pôle AAFE, Esplanade Erasme, 21065, Dijon, France \\ ${ }^{b}$ Universidad de Málaga, Departamento de Estadistica y Econometria, El Ejido s/n, 29013 Málaga, Spain
}

Received October 28, 2009; revised December 4, 2009; accepted January 14, 2010

\begin{abstract}
The purpose of this paper is to identify the main determinants of time-to-degree in higher education. Our results use retrospective data on a full cohort of first-time entering students who embarked on short and long programs from one university in Spain and who were observed over an eight-year period. The empirical results show that time-to-completion is extremely sensitive to students' abilities and, to a much lesser extent, to socio-economic background, motivation and gender. We also find that students' performance and integration at the beginning of the program reduce the time-to-degree, whereas teaching conditions do not appear to matter.
\end{abstract}

(C) 2010 Elsevier Ltd. All rights reserved.

Keywords: Higher-education; time-to-degree; survival analyis; Spain.

\section{Introduction}

Slow progress toward a degree has severe consequences for the individuals involved as well as for the society that finances most of the cost of service delivery. Having a better understanding of which students progress faster toward completion is thus important in maximizing the use of resources allocated to education and can help to develop strategies for reducing the time that students spend within the education sector.

Following the vast majority of the empirical work performed to date on student departure, our research is conducted on a single institution. The information refers to the whole population of first-year entrants at a Spanish university, who were observed for an eight-year period ending in June 2004. Based on this unique data set, which describes the school career of graduates in 46 academic programs, we estimate duration models of time-tocompletion for students enrolled in short and long programs. In tracking the educational progress of higher education graduates, we aim to identify predictors of time-to-degree involving students' characteristics, family background, academic experiences, and institutional context. In addressing these questions, the paper contributes to the growing literature on the topic (see for example, Booth and Satchell, 1995; Siegfried and Stock, 2001; Tinto, 1987). The results may be suggestive both for the individual student and potentially for university authorities and educational planners in designing policies and initiating interventions to promote faster progress toward a degree.

* Gérard Lassibille. Tel.: +33-3-80-39-54-57; fax: +33-3-80-39-54-59

E-mail address: gerard.lassibille@u-bourgogne.fr 
The remainder of the paper is set out as follows. Section 2 gives a short description of the Spanish higher education sector. Section 3 describes the data and the variables. Section 4 presents the econometric model for estimating the determinants of time-to-degree and discusses the results. Section 5 draws some conclusions and policy implications.

\section{Institutional context}

Higher education in Spain offers three distinct tracks that emphasize either academic or vocational subjects (for more details, see for example, Postlethwaite, 1995 or International Bureau of Education, 2006). Students may pursue long-cycle programs offered by the conventional university faculties. The university faculties account for a little more than 50 percent of the students in higher education. They are entitled to offer studies in all branches of knowledge, with the exception of technologies. Long-cycle programs at university faculties last between four and six years. Long-cycle professional programs are offered at higher technical schools and require five to six years of study. Fewer than 10 percent of students are enrolled in higher technical schools. Short-cycle degree programs are offered at the university schools. The studies undertaken at these colleges last three years and the programs offer a wide range of subjects. Today, university schools account for 40 percent of students enrolled in higher education.

Most programs are based on a credit system. Generally, there are no strict measures limiting the length of time in which students must complete their courses. Admission to faculties and higher technical schools is based on an entrance exam. Because of the huge demand for higher education and the limited number of places, nearly all universities in the last few years have established admission quotas. Admission to short-cycle programs is generally much less selective. However, a system of preselection exists for entry into almost all short-cycle programs. Students with a vocational education degree may enter a university school without sitting for the entrance exam.

At the macro level, very little information is available on the internal efficiency of the Spanish higher education system. No systematic information is collected to follow the schooling career of higher education students, and data published by the Ministry of Education do not make it possible to measure the system's student flow efficiency. Taking advantage of the availability of a unique set of longitudinal data, this paper looks closely into the educational progress of higher education graduates and provides estimates of the main determinants of time-to-degree.

\section{Data and variables}

Our data source is the full population of first-year entrants at the University of Málaga at the start of the academic year 1996. These students were observed over a total of eight full school years. From this database, we extract students who graduated within this period and those who were still enrolled and had not achieved the degree by our last observation date. Our final sample consists of 3.764 students enrolled in 46 programs.

The time required to complete a diploma is defined as the length of the period that elapses between initial registration in a higher education program and the date the degree is awarded. Results not shown here to save space indicate that very few students are able to complete their degree within the minimum degree time frame. Overall 39 percent of students who earn a higher education diploma do so within the intended time, while 26 percent of graduates need one additional year to complete their degree, and 35 percent require two additional years or more to graduate. However, this overall picture masks a great diversity across type of institutions and programs.

Our data set contains information about several variables that might be expected to affect time-to-degree. The control variables fall into two broad categories: preenrollment characteristics of the students and enrollment variables representing information available after students have enrolled in a particular program. The first category of variables includes gender, age at enrollment, and whether a student has experienced discontinuity between secondary school completion and higher education enrollment. We control degree times for father's education level and residency. Student's score on the preuniversity exam is included as a proxy for preenrollment academic abilities. We also include whether university school students enter into higher education with a vocational or a general secondary education diploma. This is an important aspect in the Spanish context, where up to 30 percent of university school places are reserved for students holding a vocational secondary education.

The enrollment variables include the broad subject area of the higher education degree as well as students' motivations and preferences for the program in which they are enrolled. The available data also permit an assessment of the relation between labor market status of students and time-to-completion. We control time-to- 
degree for the total number of years in the program during which students receive grants from the state. From transcript information, we calculate the percentage of credits earned to credits attempted during the first year. We also include an indication of how well a student performed in year one by calculating a student's grade-point average (GPA). Finally, among the enrollment variables, there is the scale of the graduate program, measured by the number of first-year entrants at the beginning of the observation period.

\section{Empirical results}

Following tradition, we estimate the determinants of time-to-degree by adjusting accelerated failure-time models (see Greene, 1997). Estimates of the duration models for each type of higher education program are shown in Table 1. Coefficients are reported as time ratios; values above (under) 1.0 identify predictors that increase (decrease) the elapsed-time-to-degree. We also report the marginal effects of each covariate at the sample means.

The results show that male students in three- and four-year programs take longer to earn a degree compared with their female counterparts. There is no evidence from our data of any significant gender effect in five-year and sixyear programs. Age at enrollment is positively associated with slow progress toward the degree. Even though delaying entry to higher education is generally associated with socioeconomic constraints and academic marginality that may be detrimental to the student's chances of graduation (see, for example, Bozick and DeLuca, 2005; Jacobs and King, 2002), this pattern of enrollment does not significantly slow progress toward a degree, ceteris paribus.

With regard to the other influences on time-to-degree, the regression results indicate that preenrollment academic abilities are a powerful predictor of time-to-degree. All else remaining the same, an advantage of one standard deviation above the sample mean in the preuniversity exam score shortens the expected time-to-completion from 0.4 to 0.1 year. In light of this result, reducing the entry standards to satisfy the demand for higher education from an increasing pool of secondary-school leavers who may not be equipped with the basic skills needed to succeed in higher education would have adverse effects. An equally important result is that graduate students who did not get into the course they wanted do not take significantly longer to finish than their counterparts, ceteris paribus. Otherwise stated, although current admission policies may create frustration and dissatisfaction among some individuals and may affect their chances of graduation, the mismatch between the final placement of students and their initial preferences does not seem to affect their motivation to finish quickly.

As indicated in Section 3 of this paper, up to 30 percent of university school places are reserved for students holding a vocational secondary education. According to our results, entering with a secondary vocational education slows progress by about 0.8 year relative to the time required by students who enter with a secondary general education. Obviously, this gap raises serious questions about the capacity of the vocational education system to prepare students adequately for higher education studies. Because working while attending school reduces the amount of time devoted to studying, it adversely affects student performance (see for example, Dolton, Marcenaro, and Navarro Gómez, 2003; Eckstein and Wolpin, 1999). According to our results, job responsibilities slow degree progress significantly. However, the impact of employment status varies widely across sectors. Father's education level is an indicator of the genetic ability of students and also serves as a predictor of the parent's market-earning potential that could be invested in schooling. Results show that this variable tends to exert a nonlinear effect among graduates in five-year programs and that students whose parents have an upper-secondary or higher education are more likely to earn their degree faster. Students who receive state grants continuously through the entire period of study finish faster than graduates who never receive financial support. The estimated time ratios for this variable are around 0.9 , meaning that receiving support each year reduces the time-to-degree by about 0.5 year relative to the average time required by individuals who never receive a grant during their schooling career.

Regarding academic performance at the end of year one of attendance, results show that graduates earning a higher GPA at the beginning of their schooling career take significantly less time to complete their degree. The percentage of credits earned to credits attempted is another significant contributor to time-to-degree. Graduates who earn more than 75 percent of the credits attempted during the first year of enrollment finish around two years earlier than those who earn less than 50 percent. These two findings show that how well the student is performing at the beginning of his or her schooling career is a key element in explaining progress toward the degree.

With regard to the effect of program size on time-to-degree, our results indicate that university school students in larger programs take significantly longer to complete their degree requirements. The negative impact of program 
Table 1. Determinants of time-to-degree: duration models

\begin{tabular}{|c|c|c|c|c|c|c|c|c|}
\hline & \multirow{2}{*}{\multicolumn{2}{|c|}{ University schools }} & \multicolumn{6}{|c|}{ University faculties and higher technical schools } \\
\hline & & & \multicolumn{2}{|c|}{ Four-year programs } & \multicolumn{2}{|c|}{ Five-year programs } & \multicolumn{2}{|c|}{ Six-year programs } \\
\hline & $\begin{array}{l}\text { Time } \\
\text { ratio }\end{array}$ & $\begin{array}{c}\text { Marginal } \\
\text { effect }\end{array}$ & $\begin{array}{l}\text { Time } \\
\text { Ratio }\end{array}$ & $\begin{array}{c}\text { Marginal } \\
\text { effect }\end{array}$ & $\begin{array}{l}\text { Time } \\
\text { Ratio }\end{array}$ & $\begin{array}{c}\text { Marginal } \\
\text { effect }\end{array}$ & $\begin{array}{l}\text { Time } \\
\text { Ratio }\end{array}$ & $\begin{array}{c}\text { Marginal } \\
\text { effect }\end{array}$ \\
\hline Male & $1.036 * *$ & $0.176^{* *}$ & $1.044 * * *$ & $0.245 * * *$ & 0.996 & -0.032 & 1.018 & 0.119 \\
\hline \multicolumn{9}{|l|}{ Age*Delayed enrollment } \\
\hline \multicolumn{9}{|l|}{ 19-20 years old } \\
\hline Continuous enrollment & $1.067 * * *$ & $0.325 * * *$ & $1.046^{* *}$ & $0.257 * *$ & $1.091 * * *$ & $0.709 * * *$ & 1.012 & 0.083 \\
\hline Delayed enrollment & $1.050^{*}$ & $0.247^{*}$ & 1.009 & 0.052 & $1.227 * * *$ & $1.774 * * *$ & 1.417 & 2.812 \\
\hline \multicolumn{9}{|l|}{ More than 20 years old } \\
\hline Continuous enrollment & $1.116^{* * *}$ & $0.562 * * *$ & 1.043 & 0.243 & $1.200 * *$ & $1.562 * *$ & - & - \\
\hline Delayed enrollment & $1.122 * * *$ & $0.594 * * *$ & 0.943 & -0.320 & 0.894 & -0.828 & - & - \\
\hline Normalized score at preuniversity exam & $0.951 * * *$ & $-0.250 * * *$ & $0.978 * * *$ & $-0.124 * * *$ & $0.953 * * *$ & $-0.374 * * *$ & $0.963 * *$ & $-0.258^{*}$ \\
\hline Studying chosen subject & 1.020 & 0.097 & 1.009 & 0.048 & 1.007 & 0.054 & 1.015 & 0.099 \\
\hline Entering with a vocational education diploma & $1.159 * * *$ & $0.752 * * *$ & - & - & - & - & - & - \\
\hline Paid work & $1.133 * * *$ & $0.651 * * *$ & $1.078^{*}$ & $0.437 *$ & $1.160 * *$ & $1.246^{* *}$ & $0.950 * *$ & $-0.342 *$ \\
\hline \multicolumn{9}{|l|}{ Father's education level } \\
\hline Lower-secondary education & 0.977 & -0.113 & 0.981 & -0.107 & 0.968 & -0.249 & $1.089 * *$ & $0.596^{*}$ \\
\hline Upper-secondary education & 1.009 & 0.045 & 1.013 & 0.073 & $0.953^{*}$ & $-0.367 *$ & 1.013 & 0.087 \\
\hline Higher education & 0.971 & -0.145 & 0.994 & -0.034 & $0.953^{* *}$ & $-0.377 * *$ & 1.011 & 0.075 \\
\hline Resident of the institution's home town & 1.015 & 0.072 & 1.014 & 0.075 & 1.006 & 0.049 & 0.989 & -0.073 \\
\hline \multicolumn{9}{|l|}{ Has received state financial support } \\
\hline Each year & $0.888 * * *$ & $-0.573 * * *$ & $0.905^{* * *}$ & $-0.542 * * *$ & $0.904 * * *$ & $-0.757 * * *$ & $0.929 * *$ & $-0.483^{*}$ \\
\hline Intermittently & 1.028 & 0.138 & $1.025^{*}$ & $0.141^{*}$ & 1.010 & $0.082 *$ & $1.055^{* *}$ & $0.366^{*}$ \\
\hline \multicolumn{9}{|l|}{ GPA at the end of year one } \\
\hline Between 1.5 and 2.5 & $0.933 * * *$ & $-0.343 * * *$ & $0.920 * * *$ & $-0.465 * * *$ & $0.932 * * *$ & $-0.547 * * *$ & $0.933 * * *$ & $-0.471 * *$ \\
\hline More than 2.5 & $0.905 * * *$ & $-0.470 * * *$ & $0.847 * * *$ & $-0.860 * * *$ & $0.855^{* * *}$ & $-1.144 * * *$ & $0.924 * *$ & $-0.524 * *$ \\
\hline \multicolumn{9}{|l|}{ Ratio of credits earned to credits attempted } \\
\hline Between $50 \%$ and $75 \%$ & $0.796 * * *$ & $-1.053 * * *$ & $0.846 * * *$ & $-0.885 * * *$ & $0.858 * * *$ & $-1.148 * * *$ & 0.897 & -0.700 \\
\hline More than $75 \%$ & $0.679 * * *$ & $-1.971 * * *$ & $0.727 * * *$ & $-1.908 * * *$ & $0.775^{* * *}$ & $-1.989 * * *$ & $0.846^{* *}$ & $-1.210 *$ \\
\hline Size of the entering cohort & $1.000 * * *$ & $0.002 * * *$ & 1.000 & 0.001 & 1.000 & -0.001 & - & - \\
\hline \multicolumn{9}{|l|}{ Subject area } \\
\hline Arts and human sciences & $0.909 * * *$ & $-0.464 * * *$ & $0.929 * * *$ & $-0.419 * * *$ & - & - & - & - \\
\hline Law & - & - & - & - & 0.902 & -0.790 & - & - \\
\hline Sciences & - & - & - & - & $0.818 * * *$ & $-1.515 * * *$ & - & - \\
\hline Health & $0.901 * * *$ & $-0.495^{* * *}$ & - & - & - & - & - & - \\
\hline Engineering & $1.514 * * *$ & $2.276^{* * *}$ & - & - & - & - & - & - \\
\hline Ancillary parameter & $-1.904 * * *$ & - & $-1.503 * * *$ & - & $-1.615 * * *$ & - & $-2.298 * * *$ & - \\
\hline LR chi2 & $1,743.4 * * *$ & - & $788.6 * * *$ & - & $457.8 * * *$ & - & $71.2 * * *$ & - \\
\hline Number of observations & 1,440 & - & 1,394 & - & 817 & - & 113 & - \\
\hline
\end{tabular}

size may arise from the combined influences of (a) differences in the tangible schooling environment, as reflected, for example, in a higher student-teacher ratio in larger programs; (b) differences in the effectiveness with which the available inputs are managed to promote student learning, as reflected, for example, by fewer personal interactions between students and teachers in larger programs. Finally, the results show that, after controlling for ability, preferences, socio-economic characteristics, performance at the beginning of the schooling career, and program size, significant differences do exist across subject areas. The remaining disparities in performance may be attributable to the specificities of the subject matter, which can be more or less difficult depending on the field of study. 


\section{Conclusion}

In this paper, we have applied duration models to explain the time taken to earn a higher education degree. Although the study was conducted with data from a single institution, it shed light on the completion behavior of students. As indicated previously, our results pertain to graduates in more than 40 different programs, and for this reason it is very unlikely that our conclusions reflect differences in the nature of programs offered at this one institution.

When describing the data, we found that the system's internal efficiency is low and that much room for improvement exists. Among other results, we found that preenrollment academic abilities are a significant determinant of time-to-degree, regardless of the program of study. Age at enrollment is positively associated with slow progress toward the degree and university school graduates entering with a vocational education progress significantly slower than their counterparts. We also found that financial support has a significant and positive impact on time-to-completion and we have shown that significant differences do exist across subject areas, ceteris paribus. Obviously, more research and more data clearly are needed to analyze this last issue.

Several implications for the development of education policy arise from our results. The first is the need for continued efforts to promote faster progress toward a degree. In this regard, universities could design and develop graduation interventions for at-risk students; such targeted programs would benefit both the students and the institutions. Another implication from our results is that any academic support plan designed to reduce the time-todegree of at-risk students should try to stimulate their effort and performance from the beginning of their schooling career. Policy makers could also consider administrative measures such as more systematic and tighter criteria for selecting the intake into higher education. In this regard, admission of students with a vocational educational diploma could be limited to students with good prior academic performance. Strict measures designed to limit the excessive length of time students are allowed to complete their courses should be considered too. These interventions could improve the system's performance. In the context of a meaningful expansion in the number of high school graduates, these interventions could also be one way to manage the increased pressures put on the higher education system. But equally relevant could be measures that encourage greater cost-consciousness among individuals and their families as they make educational choices at the higher education level, including greater cost sharing by students in public higher education, with appropriate features to minimize any adverse impact on those from low-income families.

\section{Acknowledgment}

The research was funded in part through a research support grant from the Ministry of Education (no. SEJ200768045-CO2-01/ECON).

\section{References}

Booth, A.L., and Satchell, S.E. (1995). The Hazards of Doing a PhD: An Analysis of Completion and Withdrawal Rates of British PhD Students in the 1980s. Journal of the Royal Statistical Society. Series A (Statistics in Society), 158, 297-318.

Bozick, R., and DeLuca, S. (2005). Better Late Than Never? Delayed Enrollment in the High School to College Transition. Social Forces, 84, 531-554.

Dolton, P., Marcenaro, O., and Navarro Gómez, L. (2003). The Effective Use of Student Time: A Stochastic Frontier Production Function Case Study. Economics of Education Review, 22, 547-560.

Eckstein, Z., and Wolpin, K. (1999). Why Youths Drop Out of High School: The Impact of Preferences, Opportunities, and Abilities. Econometrica, 67, 1295-1339.

Greene, W. (1997). Econometric Analysis. London: Prentice-Hall International.

International Bureau of Education. (2006). World Data on Education: Spain. Available at IBE website [accessed August 10, 2009].

Jacobs, J.A., and King, R.B. (2002). Age and College Completion. A Life-History Analysis of Women Aged 15-44. Sociology of Education, 75, 211-230.

Postlethwaite, T.N. (1995). International Encyclopedia of National Systems of Education (2d ed.). Oxford: Pergamon Press.

Tinto, V. (1987). Leaving college: Rethinking the causes and cures of student attrition. Chicago: University of Chicago Press.

Siegfried, J.J., and Stock, W.A. (2001). So You Want to Earn a Ph.D. in Economics? How Long Do You Think It Will Take? Journal of Human Resources, 36, 364-378. 